\title{
Bakteri dan Multiresisten Obat (Multi Drugresistance) pada Pasien dengan Kateter Urin di RSUD Petala Bumi Pekanbaru
}

\author{
Rita Endriani $^{{ }^{*}}$, Dewi Anggraini ${ }^{1}$, Rachmaliza $^{2}$, Rika Wandari ${ }^{2}$
}

\begin{abstract}
Patients with urinary catheter have an increased risk to get bacteriuria that could be develop to urinary tract infection (UTI). The aim of this study was to know sensitivity pattern and detection of ESBL in bacteria that isolated from urin of patient with urinary catheter more than 48 hours at Petala Bumi Hospital Pekanbaru. Thirty urin spesiments was growthed in blood agar and MacConkey, incubated for 18 - 24 hours. Identification bacteria was done by some of biochemical test, sensitivity test was done by Kirby Bauer method, and ESBL detection done by double disc method. Predominantly bacteria isolated was Gram negative (90\%). Gram-negative bacteria was $77.7 \%$ sensitive to chloramphenicol and fosfomycin. Gram-positive bacteria was $100 \%$ sensitive almost all antibiotic tested. Based on screening test, this study found E. coli (40\%) and Klebsiella sp, Acinetobacter sp and Pseudomonas sp (20\%) were possible produce ESBL, but ESBL was not found based on confirmatory test.
\end{abstract}

Keywords : antibacterial, bacteria, catheterization, urine

Kateterisasi adalah memasukan kateter ke dalam buli-buli melalui uretra dengan tujuan untuk diagnosis dan terapi pasien. Pasien yang menggunakan kateter terutama pasien rawat inap rentan mengalami infeksi saluran kemih (ISK). Infeksi saluran kemih tersebut dikenal sebagai ISK terkait kateter (catheter associated urinary tract infection). ${ }^{1,2}$

Berdasarkan data survey Consensus on Nosocomial Urinary Tract Infection (NUTI) pada pasien dewasa tahun 2003 sebanyak 36,3\%-42,7\% dari infeksi di rumah sakit merupakan ISK dan sebanyak $80 \%$ berkaitan dengan pemakaian kateter uretra (indwelling urinary catheter) ${ }^{3,4}$ Berdasarkan The Center for Disease Control and Prevention (CDC) risiko ISK dengan kateterisasi terjadi dari 2-10 hari sebesar 26\%, dengan resiko infeksi perhari sebesar 3-10\%.5,6 Penelitian yang dilakukan oleh Domingo KB et al, menunjukkan ISK terkait kateter lebih banyak terjadi pada wanita $(52,7 \%)$ dibandingkan pria $(47,3 \%)$. Penelitian yang sama

\footnotetext{
* Penulis untuk korespondensi :

1 Bagian Mikrobiologi, Fakultas Kedokteran, Universitas Riau

2 Fakultas Kedokteran, Universitas Riau
}

menunjukkan bahwa ISK terkait kateter pada umur dibawah 30 tahun kejadiannya sebanyak 13,6\%, pada umur 31-50 tahun sebanyak 33,6\%, pda umur 51-70 tahun sebanyak $36,4 \%$, dan pada umur di atas 70 tahun sebanyak $16,4 \%$. $^{7}$

Bakteri yang sering ditemukan pada pasien yang menggunakan kateter adalah E. coli, Klebsiella sp., Proteus sp., Staphylococci, Pseudomonas aeruginosa, Enterococci. ${ }^{7,8}$ Penelitian lain melaporkan bakteri terbanyak adalah Gram negatif $(57,89 \%)$ terdiri dari E. coli, Enterobacter $s p$, Klebsiella sp, danPseudomonas sp. dan Gram positif $(42,11 \%)$ terdiri dari Staphylococcus saprophytic, Staphylococcus epidermidis, Staphylococcus aureus dan Streptococcus sp. ${ }^{9}$

Peningkatan kasus ISK terkait kateter juga diikuti dengan peningkatan pemakaian antibiotik untuk mengatasi infeksi tersebut. Pengobatan ISK dengan menggunakan antibiotik yang sesuai dan rasional dapat menekan biaya pengobatan, mencegah komplikasi lanjutan dari infeksi saluran kemih, dan mencegah resistensi terhadap berbagai antibiotika. ${ }^{6}$ Penelitian mengenai resistensi antibakteri pada pasien dengan kateterisasi urin di 
RSUD Arifin Achmad Pekanbaru melaporkan bahwa resistensi tertinggi ditemukan pada cefotaxim, cefriaxon, cefalexin dan tetracyclin yaitu $100 \%$. Selain itu resistensi yang terendah ditemukan pada merofenem dan trimetoprimsulfametoxazol yaitu $73,68 \% .^{10}$

Antibiotik yang merupakan lini pertama untuk mengatasi ISK yang berspektrum luas terutama golongan antibotik â laktam. Pemakaian antibiotik ini akan berdampak pada munculnya resistensi antibiotik golongan â laktam pada bakteri penyebab ISK. ${ }^{11}$ Resistensi bakteri terhadap golongan antibiotik beta laktam bisa terdapat pada golongan Gram positif yang disebut Methicillin Resistant Staphylococcus aureus (MRSA) merupakan strain bakteri Staphylococcus aureus yang resisten terhadap antibiotik Methicillin. Saat ini diperkirakan sekitar 2-3\% populasi umum telah terkolonisasi oleh bakteri MRSA.${ }^{12}$ Selain itu juga bisa terjadi pada golongan Gram negatif yang menghasilkan enzim terkait plasmid berupa Extended Spectrum Beta Lactamase ( ESBL). ${ }^{10}$

Penelitian di RS. Dr. Soetomo melaporkan $72,2 \%$ pasien pria yang menggunakan kateter teridentifikasi bakteri penghasil ESBL. ${ }^{13}$ Penelitian di RS. Dr. Kariadi menemukan isolat bakteri penghasil ESBL pada material urogenitalia sebesar 14,29\%. ${ }^{14}$ Peneliti lain melaporkan hasil pemeriksaan urin pasien di RSUD Arifin Achmad Provinsi Riau menemukan bakteri batang Gram negatif yang teridentifikasi ESBL pada skrining awal adalah E. coli dan Enterobacter $s p$ masingmasing (36,36\%), Pseudomonas sp $(18,18 \%)$ dan Klebsiella sp $(9,10 \%)$. Pada uji konfirmasi yang teridentifikasi adalah E. coli $(66,67 \%)$ dan Klebsiella sp $(33,33 \%) .{ }^{10}$

Rumah Sakit Umum Daerah (RSUD) Petala Bumi Pekanbaru merupakan rumah sakit rujukan sehingga pemakaian kateter juga tinggi. Hal ini akan berdampak pada meningkatnya risiko infeksi ISK terkait kateter. Belum adanya data mengenai ISK yang disebabkan oleh bakteri, resistensi antibakteri dan bakteri multi resisten antibakteri berupa MRSA dan ESBL di RS Petala Bumi sehingga peneliti ingin mengetahui bakteri dan resistensinya pada pasien ISK dengan kateterisasi urin di RS Petala Bumi Pekanbaru.

\section{METODE}

Penelitian ini merupakan penelitian deskriptif laboratorik prospektif yang dilaksanakan selama 6 bulan di RSUD Petala Bumi Pekanbaru dan laboratorium Mikrobiologi FK UR.Subjek penelitian adalah pasien rawat inap yang menggunakan kateter setelah 48 jam di RSUD Petala Bumi Pekanbaru. Sampel penelitian ini adalah urin pasien yang keluar melalui kateter diambil dengan Indwelling catheter urine. Sampel merupakan sampel konsekutif tidak acak (non random consecutive sampling).

Alat-alat dan bahan yang digunakan dalam penelitian ini adalah alat-alat dan bahan yang biasa digunakan untuk kultur, identifikasi bakteri dan uji resistensi di Laboratorium Mikrobiologi FK UR seperti, lidi kapas steril, osse, bunsen, inkubator, laminar flow, sarung tangan, BD syringe $10 \mathrm{cc}$, mikroskop, klem non-traumatik, kaca objek, pipet mikro, kotak dingin dengan paket es, pot urin, kapas alkohol. Bahan-bahannya antara lain spesimen urin, lempeng agar darah, lempeng agar Endo, lempeng agar Mueller-Hinton, serta bahan reaksi, larutan $\mathrm{NaCl}$ fisiologis, pewarnaan Gram, cakram berbagai antibiotik.

Sebelum pengambilan sampel urin, pasien atau keluarga pasien menadatangani inform consent. Pengambilan urin dilakukan dengan Indwelling catheter urine yang diambil sebanyak 5-10 ml. Spesimen urin diperiksa sebelum 2 jam setelah pengambilan dan dibawa ke Laboratorium Mikrobiologi FK UR. Sampel urin selanjutnya dikultur pada agar darah dan agar Endo sebanyak $0,05 \mathrm{ml}$ dan diinkubasikan pada suhu $37^{\circ} \mathrm{C}$ selama 24 jam. Kemudian dari bakteri yang tumbuh dilakukan hitung koloni dan identifikasi koloni berdasarkan makroskopis, mikroskopis dengan pewarnaan Gram, reaksi biokimia, tes katalase, tes koagulase dan uji novobisin. Untuk MRSA dilakuakn test dengan cakram cefoksitin $(30 \mu \mathrm{g})$ pada agar Mueller-Hinton yang telah diinokulasi kemudian diinkubasi selama 24 jam pada suhu 35$37^{\circ} \mathrm{C}$. Untuk uji ESBL dilakukan denga uji kepekaan antibiotik awal (presumtif ESBL) dan dilanjutkan dengan uji lanjutan (konfirmasi) ESBL Disk Approximate Method untuk mendeteksi bakteri batang Gram negatif penghasil ESBL.Setelah itu dilanjutkan dengan uji resistensi bakteri terhadap antibakteri dilakukan dengan metode Kirby Bauer/ 
difusi cakram seperti yang direkomendasikan oleh Clinical and Laboratory Standard Institute (CLSI).

\section{HASIL DAN PEMBAHASAN}

\section{Karaterisitik Pasien dengan Kateterisasi Urin}

Penelitian ini dilakukan di RSUD Petala Bumi Pekanbaru dan Laboratorium Mikrobiologi Fakultas
Kedokteran Universitas Riau dengan jumlah sampel sebanyak 30 pasien yang menggunakan kateter urin di RSUD Petala Bumi Pekanbaru yang memenuhi kriteria inklusi dan ekslusi. Karakteristik pasien yang menggunakan kateter urin dapat dilihat pada Tabel 1.

Tabel 1.Karakteristik subjek penelitian

\begin{tabular}{|c|c|c|c|c|c|c|c|}
\hline \multirow{2}{*}{ No. } & \multirow{2}{*}{ Subjek penelitian } & \multicolumn{2}{|c|}{ Bakteriuria } & \multicolumn{2}{|c|}{$\begin{array}{c}\text { Non- } \\
\text { bakteriuria }\end{array}$} & \multicolumn{2}{|c|}{ Total sampel } \\
\hline & & $\mathbf{N}$ & $\%$ & $\mathbf{n}$ & $\%$ & $\mathbf{N}$ & $\%$ \\
\hline \multirow[t]{11}{*}{1} & Umur & & & & & & \\
\hline & $0-5$ tahun & - & - & - & - & - & - \\
\hline & 5-11 tahun & - & - & - & - & - & - \\
\hline & 12-16 tahun & - & - & - & - & - & - \\
\hline & 17-25 tahun & - & - & 2 & 100 & 2 & 6,6 \\
\hline & 26-35 tahun & - & - & 5 & 100 & 5 & 16,6 \\
\hline & 36-45 tahun & 2 & 50 & 2 & 50 & 4 & 13,3 \\
\hline & $46-55$ tahun & 4 & 50 & 4 & 50 & 8 & 26,6 \\
\hline & $56-65$ tahun & 1 & 25 & 3 & 75 & 4 & 13,3 \\
\hline & $>65$ tahun & 3 & 42,8 & 4 & 57,1 & 7 & 23,3 \\
\hline & Total sampel & & & & & 30 & 100 \\
\hline \multirow[t]{4}{*}{2} & Jenis kelamin & & & & & & \\
\hline & Pria & 2 & 25 & 6 & 75 & 8 & 26,6 \\
\hline & Wanita & 8 & 36,3 & 14 & 63,6 & 22 & 73,3 \\
\hline & Total sampel & & & & & 30 & 100 \\
\hline \multirow[t]{5}{*}{3} & Lama pemakaian & & & & & & \\
\hline & 2 - 5 hari & 6 & 25 & 18 & 75 & 24 & 80 \\
\hline & $>5-7$ hari & 3 & 75 & 1 & 25 & 4 & 13,3 \\
\hline & $>7$ hari & 1 & 50 & 1 & 50 & 2 & 6,6 \\
\hline & Total sampel & & & & & 30 & 100 \\
\hline \multirow[t]{7}{*}{4} & Jumlah koloni & & & & & & \\
\hline & $<10^{3}$ & - & - & - & - & - & - \\
\hline & $10^{3}-10^{4}$ & - & - & - & - & - & - \\
\hline & $10^{4}-10^{5}$ & - & - & - & - & - & - \\
\hline & $>10^{5}$ & 10 & 100 & - & - & 10 & 33,3 \\
\hline & Tidak ada pertumbuhan & - & - & 20 & 100 & 20 & 66,6 \\
\hline & Total sampel & & & & & 30 & 100 \\
\hline
\end{tabular}


Karakteristik subjek penelitian berdasarkan usia yang terbanyak yaitu usia $46-55$ tahun $(26,6 \%)$, wanita $(73,3 \%)$, lama pemakaian kateter selama 25 hari $(80 \%)$. Seluruh sampel yang mengalami pertumbuhan bakteri adalah dengan jumlah koloni $>10^{5}(100 \%)$.

Usia pasien mempengaruhi risiko terjadinya bakteriuria sebagai penyebab ISK. Pada penelitian ini didapatkan pasien dengan bakteriuria tertinggi kedua adalah usia $>65$ tahun dengan persentase $42,8 \%$. Penelitian lain menyatakan bahwa pasien dengan usia $>55$ tahun memiliki risiko mengalami ISK kateter 5,57 kali lebih besar dibandingkan pasien dengan usia < 55 tahun. ${ }^{15}$ Al-Hazmi dkk melaporkan bahwa pasien usia lanjut memiliki risiko 1,4 kali lebih besar untuk mengalami ISK terkait kateter dibandingkan pasien dengan usia muda. Penelitian ini juga menyebutkan bahwa $51,8 \%$ pasien diatas 62 tahun mengalami infeksi saluran kemih nosokomial. ${ }^{16}$

Pasien usia dewasa hingga lanjut usia lebih rentan mengalami ISK kateter dibandingkan pasien usia muda. Pada wanita dewasa hingga lanjut usia hal ini oleh karena terjadinya atrofi epitelium uretra yang menyebabkan penurunan fungsi barrier fisik uretra dalam mempertahankan sterilitas kandung kemih. Pada laki-laki ini disebabkan karena penurunan sekresi prostat yang dapat menurunkan kemampuan menghambat aktivitas antibakterial pada uretra dan kandung kemih. ${ }^{17}$ Penelitian yang dilakukan oleh Sari EWP dkk. menyatakan bahwa pasien dengan usia $>55$ tahun memiliki risiko mengalami ISK kateter 5,57 kali lebih besar dibandingkan pasien dengan usia $<55$ tahun. ${ }^{18}$ Penelitian lain yang dilakukan oleh Al-Hazmi dkk. menyebutkan bahwa pasien usia lanjut memiliki risiko 1,4 kali lebih besar untuk mengalami ISK terkait kateter dibandingkan pasien dengan usia muda. Penelitian ini juga menyebutkan bahwa $51,8 \%$ pasien diatas 62 tahun mengalami infeksi saluran kemih nosokomial. ${ }^{16}$
Pasien yang menggunakan kateter urin di RSUD Petala Bumi Pekanbaru terbanyak adalah pasien dengan jenis kelamin wanita, dengan jumlah sampel bakteriuria sebanyak 8 sampel (36,3\%). Hal ini sesuai dengan teori yang menyatakan bahwa wanita cenderung lebih mudah mengalami bakteriuria yang menjadi penyebab ISK dibandingkan pria karena adanya perbedaan anatomi uretra antara wanita dan pria. Hal ini sejalan dengan penelitian yang dilakukan oleh Karjono BJ dkk. dilaporkan bahwa jenis kelamin wanita $(68,4 \%)$ lebih sering mengalami ISK dibandingkan dengan pria $(31,6 \%) .{ }^{17}$

Berdasarkan lama pemakaian kateter, menyatakan bahwa semakin lama penggunaan kateter akan semakin meningkatkan risiko bakteriuria sebagai penyebab ISK terkait kateter. Berdasarkan The Center for Disease Control and Prevention (CDC) risiko ISK dengan kateterisasi terjadi dari 2-10 hari sebesar $26 \%$, dengan resiko infeksi perhari sebesar 3-10\%., Pasien dengan bakteriuria di RSUD Petala Bumi Pekanbaru seluruhnya (100\%) adalah pasien dengan jumlah koloni $>10^{5} \mathrm{cfu} / \mathrm{mL}$. Penggunaan kateter urin menjadi faktor penyebab terjadinya bakteriuria. Salah satu penelitian tentang angka kejadian bakteriuria terkait penggunaan kateter urin di panti jompo menyebutkan bahwa dari 200 sampel penelitian hampir 95\% didapatkan jumlah koloni e" $50.000 \mathrm{cfu} / \mathrm{mL} .{ }^{19}$ Hasil penelitian ini menunjukan bahwa dengan jumlah koloni $>10^{5} \mathrm{cfu} / \mathrm{mL}$ semakin meningkatkatkan risiko terjadinya ISK kateter, meskipun sekarang ini diagnosis ISK kateter lebih ditekankan kepada gejala klinis.

\section{Hasil Kultur Urin dan Identifikasi bakteri}

Setelah dilakukan pengambilan urin selanjutnya dilakukan kultur dan hasil kultur tersebut dapat dilihat pada tabel 2. 
Tabel 2. Pola bakteri

\begin{tabular}{|c|c|c|c|}
\hline No. & Jenis bakteri & $\mathbf{n}$ & $\%$ \\
\hline \multirow[t]{5}{*}{1} & Gram negatif & 9 & 90 \\
\hline & Escherichia coli & 5 & 55,5 \\
\hline & Acinetobacter sp & 2 & 22,2 \\
\hline & Klebsiella sp & 1 & 11,1 \\
\hline & Pseudomonas sp & 1 & 11,1 \\
\hline \multirow[t]{2}{*}{2} & Gram positif & 1 & 10 \\
\hline & Staphylococcus aureus & 1 & 100 \\
\hline & Total sampel & 10 & 100 \\
\hline
\end{tabular}

\section{Hasil Uji Sensitivitas Bakteri Terhadap Berbagai Antibiotik}

Tabel 3.Pola sensitivitas bakteri Gram negatif

\begin{tabular}{|c|c|c|c|c|c|c|c|c|}
\hline \multirow{3}{*}{ No. } & \multirow{3}{*}{ Antibakteri } & \multicolumn{6}{|c|}{ Frekuensi } & \multirow{3}{*}{$\mathbf{N}$} \\
\hline & & \multicolumn{2}{|c|}{$\mathbf{S}$} & \multicolumn{2}{|c|}{ I } & \multicolumn{2}{|c|}{$\mathbf{R}$} & \\
\hline & & $\mathbf{N}$ & $\%$ & $\mathbf{n}$ & $\%$ & $\mathbf{N}$ & $\%$ & \\
\hline 1 & Amikasin $(A K)$ & 6 & 66,6 & 2 & 22,2 & 1 & 11,1 & 9 \\
\hline 2 & Ampicillin (AMP) & 3 & 33,3 & - & - & 6 & 66,9 & 9 \\
\hline 3 & Amoxicillin-clavulanat (AMC) & 4 & 44,4 & 1 & 11,1 & 4 & 44,4 & 9 \\
\hline 4 & Cefazolin (KZ) & 4 & 50 & - & - & 4 & 50 & 8 \\
\hline 5 & Cefepime (FEP) & 4 & 50 & - & - & 4 & 50 & 8 \\
\hline 6 & Ceftazidime (CAZ) & 4 & 44,4 & - & - & 5 & 55,5 & 9 \\
\hline 7 & Ceftriaxone (CRO) & 4 & 44,4 & - & - & 5 & 55,5 & 9 \\
\hline 8 & Chloramphenicol (C) & 7 & 77,7 & - & - & 2 & 22,2 & 9 \\
\hline 9 & Ciprofloxacin (CIP) & 3 & 33,3 & 1 & 11,1 & 5 & 55,5 & 9 \\
\hline 10 & Fosfomycin (FOS) & 7 & 77,7 & - & - & 2 & 22,2 & 9 \\
\hline 11 & Gentamicin ( CN) & 6 & 66,6 & 1 & 11,1 & 2 & 22,2 & 9 \\
\hline 12 & Levofloxacin (LEV) & 4 & 44,4 & - & - & 5 & 55,5 & 9 \\
\hline 13 & Meropenem (MEM) & 5 & 55,5 & 1 & 11,1 & 3 & 33,3 & 9 \\
\hline 14 & Piperacillin-tazobactam (TZP) & 5 & 55,5 & 2 & 22,2 & 2 & 22,2 & 9 \\
\hline 15 & $\begin{array}{l}\text { Trimethroprim-sulfamethoxazol } \\
(\text { SXT) }\end{array}$ & 2 & 33,3 & - & - & 4 & 66,6 & 6 \\
\hline 16 & Tigecyclin $(T G C)$ & 6 & 66,6 & - & - & 3 & 33,3 & 9 \\
\hline
\end{tabular}

Keterangan : $\mathrm{S}=$ Sensitif, $\mathrm{I}=$ Intermediet, $\mathrm{R}=$ Resisten 
Berdasarkan hasil pada tabel 2. didapatkan bakteri terbanyak adalah Gram negatif (90\%), berupa Escherichia coli (55,5\%). Penelitian yang dilakukan Karjono BJ dkk menyebutkan bakteri terbanyak pada pasien ISK kateter adalah E.coli (40\%) dan Pseudomonas sp (40\%). ${ }^{17}$

Bakteri Gram negatif terutama E. coli Uropatogenik (Uropathogenic E. coli/UPEC) merupakan bakteri terbanyak yang menyebabkan bakteriuria hingga ISK termasuk ISK dengan kateterisasi. Hal ini disebabkan karena bakteri ini merupakan flora normal yang dapat menimbulkan penyakit pada keadaan tertentu misalnya pada saat sistem pertahanan tubuh menurun. Selain itu juga memiliki fimbriae/ pili yang memudahkan perlekatan dengan uroepitelium saluran kemih dan juga merupakan opportunistik yang mudah menimbulkan penyakit pada penderita dengan sistem imun yang menurun. UPEC juga bisa menyebabkan nefropatogenik yang secara khas menghasilkan hemolisin dan urease. ${ }^{20}$ Selain bakteri Gram negatif juga ditemukan bakteri Gram positif (10\%), yaitu Staphylococcus aureus (100\%).
Penelitian ini sejalan dengan penelitian yang dilakukan oleh Mody L dkk. didapatkan bakteri Gram positif yang ditemukan sebagai penyebab ISK kateter yaitu Staphylococcus aureus $(15,3 \%)$ dan Staphylococcus epidermidis $(7,7 \%) .{ }^{19}$

Berdasarkan Tabel 3 antibakteri yang memiliki sensitivitas paling tinggi terhadap bakteri Gram negatif adalah chloramphenicol dan fosfomycin dengan persentase masing-masing $77,7 \%$. Chloramphenicol merupakan antibakteri yang bekerja dengan menghambat sintesis protein bakteri. Antibakteri ini umumnya sensitif padaS. aureus, $E$. coli, K. pneumoniae dan P. mirabilis. ${ }^{21}$ Fosfomycin merupakan antibiotik yang bersifat bakterisidal.Sebuah literatur menyebutkan fosfomycin digunakan utuk terapi ISK tanpa komplikasi. Fosfomycin memiliki nilai toksisitas dan resistensi silang yang rendah dengan antibiotik lain. Antibiotik ini dapat dianggap sebagai alternatif untuk pengobatan infeksi baik akibat Gram negatif maupun Gram positif, terutama dalam kasus yang melibatkan patogen resisten yang sebelumnya gagal dengan pengobatan antibakteri lainnya. ${ }^{22}$.

Tabel 4. Pola sensitivitas bakteri Gram positif

\begin{tabular}{|c|c|c|c|c|c|c|c|c|}
\hline \multirow{3}{*}{ No. } & \multirow{3}{*}{ Antibakteri } & \multicolumn{7}{|c|}{ Frekuensi } \\
\hline & & \multicolumn{2}{|c|}{$\mathrm{S}$} & \multicolumn{2}{|c|}{ I } & \multicolumn{2}{|c|}{$\mathrm{R}$} & \multirow{2}{*}{$\mathrm{N}$} \\
\hline & & $\mathrm{n}$ & $\%$ & $\mathrm{~N}$ & $\%$ & $\mathrm{~N}$ & $\%$ & \\
\hline 1 & Ampicillin (AMP) & - & - & - & - & 1 & 100 & 1 \\
\hline 2 & Amoxicillin-clavulanat (AMC) & 1 & 100 & - & - & - & - & 1 \\
\hline 3 & Azytromicin $(A Z T)$ & 1 & 100 & - & - & - & - & 1 \\
\hline 4 & Cefazolin (KZ) & 1 & 100 & - & - & - & - & 1 \\
\hline 5 & Cefepime (FEP) & 1 & 100 & - & - & - & - & 1 \\
\hline 6 & Cefoxcitin (FOX) & 1 & 100 & - & - & - & - & 1 \\
\hline 7 & Ceftriaxone (CRO) & 1 & 100 & - & - & - & - & 1 \\
\hline 8 & Chloramphenicol (C) & 1 & 100 & - & - & - & - & 1 \\
\hline 9 & Ciprofloxacin (CIP) & 1 & 100 & - & - & - & - & 1 \\
\hline 10 & Gentamicin (CN) & - & - & - & - & 1 & 100 & 1 \\
\hline 11 & Levofloxacin (LEV) & - & - & - & - & 1 & 100 & 1 \\
\hline 12 & Linezolid (LZD) & 1 & 100 & - & - & - & - & 1 \\
\hline 13 & Meropenem (MEM) & 1 & 100 & - & - & - & - & 1 \\
\hline 14 & Trimethro-sulfa (SXT) & 1 & 100 & - & - & - & - & 1 \\
\hline
\end{tabular}

Keterangan : $\mathrm{S}=$ Sensitif, $\mathrm{I}=$ Intermediet, $\mathrm{R}=$ Resisten 
Berdasarkan Tabel.4 bakteri Gram positif $100 \%$ sensitif terhadap amoxicillin-clavulanat, azytromicin, cefazolin, cefepime, cefoxcitin, ceftriaxon, chloramphenicol, ciprofloxacin, linezolid, meropenem dantrimethropimsulfamethoxazol.

Tabel 5. Pola sensitivitas masing-masing bakteri

\begin{tabular}{|c|c|c|c|c|c|c|c|c|c|c|c|c|c|c|c|c|}
\hline \multirow{3}{*}{ No. } & \multirow{3}{*}{ Antibakteri } & \multirow{2}{*}{\multicolumn{3}{|c|}{$\begin{array}{c}\text { E.coli }(\%) \\
\mathrm{n}=5 \\
\end{array}$}} & \multirow{2}{*}{\multicolumn{3}{|c|}{$\begin{array}{c}\text { Acineto }(\%) \\
\mathrm{n}=2\end{array}$}} & \multirow{2}{*}{\multicolumn{3}{|c|}{$\begin{array}{c}\text { Klebsiella }(\%) \\
\mathrm{n}=1\end{array}$}} & \multirow{2}{*}{\multicolumn{3}{|c|}{$\begin{array}{c}\text { Pseud (\%) } \\
\mathrm{n}=1\end{array}$}} & \multirow{2}{*}{\multicolumn{3}{|c|}{$\begin{array}{c}\text { S. aureus (\%) } \\
\mathrm{n}=1\end{array}$}} \\
\hline & & & & & & & & & & & & & & & & \\
\hline & & $\mathbf{S}$ & $\mathbf{I}$ & $\mathbf{R}$ & $\mathbf{S}$ & I & $\mathbf{R}$ & $\mathbf{S}$ & I & $\mathbf{R}$ & $\mathbf{S}$ & $\mathbf{I}$ & $\mathbf{R}$ & $\mathbf{S}$ & $\mathbf{I}$ & $\mathbf{R}$ \\
\hline 1 & Amikasin (AK) & 60 & 20 & 20 & 50 & 50 & - & 100 & - & - & 100 & - & - & - & - & - \\
\hline 2 & Ampicillin (AMP) & 40 & - & 60 & 50 & - & 50 & - & - & 100 & - & - & 100 & - & - & 100 \\
\hline 3 & Amox-clav (AMC) & 60 & - & 40 & 50 & - & 50 & - & 100 & - & - & - & 100 & 100 & - & - \\
\hline 4 & Azytromicin (AZT) & - & - & - & - & - & - & - & - & - & - & - & - & 100 & - & - \\
\hline 5 & Cefazolin (KZ) & 60 & - & 40 & 50 & - & 50 & - & - & - & - & - & 100 & - & - & - \\
\hline 6 & Cefepime (FEP) & 60 & - & 40 & 50 & & 50 & - & - & 100 & - & - & - & 100 & - & - \\
\hline 7 & Ceftazidime (CAZ) & 60 & - & 40 & 50 & - & 50 & - & - & 100 & - & - & 100 & - & - & - \\
\hline 8 & $\begin{array}{l}\text { Ceftriaxone } \\
(C R O)\end{array}$ & 60 & - & 40 & 50 & - & 50 & - & - & 100 & - & - & 100 & 100 & - & - \\
\hline 9 & Cefoxcitin (FOX) & - & - & - & - & - & - & - & - & - & - & - & - & 100 & - & - \\
\hline 10 & $\begin{array}{l}\text { Chloramphenicol } \\
\text { (C) }\end{array}$ & 100 & - & - & 50 & - & 50 & 100 & - & - & - & - & 100 & - & - & - \\
\hline 11 & $\begin{array}{l}\text { Ciprofloxacin } \\
\text { (CIP) }\end{array}$ & 20 & 20 & 60 & 50 & - & 50 & - & - & 100 & 100 & - & - & 100 & - & - \\
\hline 12 & $\begin{array}{l}\text { Fosfomycin } \\
\text { (FOS) }\end{array}$ & 80 & - & 20 & 50 & - & 50 & 100 & - & - & 100 & - & - & & - & \\
\hline 13 & Gentamicin $(C N)$ & 60 & 20 & 20 & 50 & - & 50 & 100 & - & - & 100 & - & - & - & - & 100 \\
\hline 14 & $\begin{array}{l}\text { Levofloxacin } \\
\text { (LEV) }\end{array}$ & 40 & - & 60 & 50 & - & 50 & - & - & 100 & 100 & - & - & - & - & 100 \\
\hline 15 & Linezolid (LZD) & - & - & - & - & - & - & - & - & - & - & - & - & 100 & - & - \\
\hline 16 & $\begin{array}{l}\text { Meropenem } \\
(M E M)\end{array}$ & 40 & - & 60 & 50 & 50 & - & 100 & - & - & 100 & - & - & 100 & - & - \\
\hline 17 & Pip-tazo $(T Z P)$ & 40 & 20 & 40 & 50 & 50 & - & 100 & - & - & 100 & - & - & - & - & - \\
\hline 18 & $\begin{array}{l}\text { Trimethro- } \\
\text { sulfa }(S X T)\end{array}$ & 25 & - & 75 & 100 & - & - & - & - & - & - & - & 100 & 100 & - & - \\
\hline 19 & Tygeciclin (TGC) & 100 & - & - & 50 & - & 50 & - & - & 100 & - & - & 100 & - & - & - \\
\hline
\end{tabular}

Keterangan : $\mathrm{S}=$ Sensitif, $\mathrm{I}=$ Intermediet, $\mathrm{R}=$ Resisten

Berdasarkan jenis bakteri yang dominan dalam penelitian ini didapatkan E.coli $100 \%$ sensitif terhadap chloramphenicol, tigecyclindan memiliki sensitivitas yang cukup rendah $(40 \%)$ terhadap levofloxcacin. Chloramphenicol merupakan antibakteri yang bekerja dengan menghambat sintesis protein bakteri. Obat ini efektif terhadap kebanyakan strain $E$. coli, hal ini sejalan dengan hasil penelitian yang telah dilakukan. Mekanisme resistensi terhadap chloramphenicol terjadi melalui inaktivasi obat oleh asetil transferase yang diperantarai oleh faktor-R. Selain efektif terhadap strain E.coli antibakteri ini dapat resisten terhadap
Pseudomonas aeruginosa. Hal ini sejalan dengan hasil penelitian yang telah dilakukan bahwa chloramphenicol $100 \%$ resisten pada Pseudomonas $s p$.

Antibakteri dengan angka resistensi tertinggi (75\%) terhadap E.coli yaitu trimethroprimsulfamethoxazol. Hal ini berbeda dengan penelitian yang dilakukan oleh Endriani R dkk. didapatkan antibakteri dengan angka resistensi tertinggi (100\%) terhadap E.coli yaitu clindamycin, pipemidic acid, penicilin $G$ dan streptomycin. Hal ini menunjukkan bahwa pada waktu dan tempat yang berbeda pola 
bakteri dapat mengalami perubahan sehingga diperlukan laporan mengenai pola dan sensitivitas antibakteri yang selalu baru.Untuk mencegah terjadinya resistensi rasionalitas penggunaan antibakteri sangatlah penting. Beberapa hal yang menjadi tolak ukur rasionalitas penggunaan antibakteri yaitu tepat indikasi, tepat obat, tepat dosis, tepat durasi dan tepat frekuensi. Antibakteri yang rasional dipilih berdasarkan uji sensitivitas bakteri. ${ }^{10}$

Tabel 6. Hasil identifikasi ESBL pada uji skrining

\begin{tabular}{llll}
\hline No & Hasil uji skrining ESBL & Frekuensi (n) & Persentase (\%) \\
\hline 1. & Positif & 5 & $55,55 \%$ \\
2. & Negatif & 4 & $44,45 \%$ \\
\hline & Total & $\mathbf{9}$ & $\mathbf{1 0 0}$ \\
\hline
\end{tabular}

Berdasarkan Tabel.6 dari hasil uji skrining ESBL pada bakteri Gram negatif didapatkan ESBL positif sebanyak 5 sampel $(55,55 \%)$.

Tabel 7. Identifikasi bakteri Gram negatif berdasarkan uji skrining ESBL

\begin{tabular}{|c|c|c|c|c|c|c|}
\hline \multirow[t]{2}{*}{ No } & \multirow[t]{2}{*}{ Jenis bakteri } & \multicolumn{2}{|c|}{ Uji skrining ESBL } & \multicolumn{2}{|c|}{ Uji skrining ESBL } & \multirow[t]{2}{*}{ Total } \\
\hline & & Positif & Persentase & Negatif & Persentase & \\
\hline 1. & Escherichia coli & 2 & $40 \%$ & 3 & $60 \%$ & 5 \\
\hline 2. & Klebsiella sp & 1 & $100 \%$ & 0 & $0 \%$ & 1 \\
\hline 3. & Acinetobacter sp & 1 & $50 \%$ & 1 & $50 \%$ & 2 \\
\hline 4. & Pseudomonas sp & 1 & $100 \%$ & 0 & $0 \%$ & 1 \\
\hline & Total & & & & & 9 \\
\hline
\end{tabular}

Berdasarkan Tabel 7 menurut uji skrining didapatkan ESBL positif yang terbanyak dihasilkan oleh Escherichia coli sebanyak 2 sampel (40\%) dan

Tabel 8. Hasil identifikasi ESBL pada uji konfirmatif uji skrining dengan ESBL negatif sebanyak 3 sampel (60\%).

\begin{tabular}{llll}
\hline No & Hasil uji konfirmatif & Frekuensi (n) & Persentase (\%) \\
\hline 1. & ESBL positif & 0 & $0 \%$ \\
2. & ESBL negatif & 5 & $100 \%$ \\
\hline & Total & $\mathbf{5}$ & $\mathbf{1 0 0}$ \\
\hline
\end{tabular}

Berdasarkan Tabel 8 dari hasil uji konfirmatif pada bakteri Gram negatif tidak didapatkan ESBL positif. Berdasarkan uji skrining didapatkan 5 bakteri yang kemungkinan menghasilkan ESBL yaitu Escherichia coli sebanyak 2 sampel (40\%), dan Klebsiella sp, Acinetobacter sp, Pseudomonas $s p$ masing-masing sebanyak 1 sampel $(20 \%)$. Setelah dilakukan uji skrining, bakteri yang kemungkinan menghasilkan ESBL tersebut dilanjutkan dengan uji konfirmatif dengan metode double disk. Hasil uji konfirmatif tidak didapatkan bakteri batang Gram negatif yang menghasilkan Extended Spectrum Beta Lactamase (ESBL).

Hasil penelitian ini berbeda dengan penelitianpenelitian yang dilakukan sebelumnya.

Hasil penelitian berbeda dengan penelitian Endriani R dkk di RSUD Arifin Achmad Provinsi Riau pada skrining awal bakteri batang Gram negatif penghasil ESBL yang terbanyak adalah $E$. 
coli dan Enterobacter sp masing-masing (36,36\%)., Pseudomonas sp $(18,18 \%)$ dan Klebsiella $s p$ $(9,10 \%)$. Pada uji konfirmasi yang teridentifikasi ESBL yaitu E. coli $(66,67 \%)$ dan Klebsiella sp $(33,33 \%) .{ }^{10}$ Penelitian yang dilakukan oleh Yuwono di RSUP Moh. Husein Palembang melaporkan bakteri penghasil ESBL dari spesimen urin terbanyak dihasilkan oleh Klebsiella $s p$ yaitu 30 sampel $(40,00 \%) \cdot{ }^{24}$

Terjadinya ESBL yang dihasilkan oleh bakteri Gram negatif bisa disebabkan oleh beberapa faktor diantaranya keparahan penyakit, lama rawat inap dirumah sakit, peralatan medis yang invasif (kateter urin, endotracheal tubes) dan penggunaan antibiotik cephalosporin generasi III secara luas untuk pengobatan penyakit infeksi. ${ }^{24}$ Resistensi cephalosporin selain disebabkan oleh ESBL bisa juga disebabkan karena AmpC. Berbeda dengan ESBL, AmpCbeta lactamase bisa mengnonaktifkan cephamycin dan tidak dihambat oleh inhibitor beta lactamase seperti clavulanic acid. ${ }^{25}$

Tidak ditemukannya bakteri gram negatif penghasil ESBL bisa juga disebabkan karena metode ESBL yang diujikan pada penelitian ini hanya menggunakan metode double disk pada uji konfirmatif untuk mendeteksi bakteri Gram negatif penghasil ESBL. Deteksi ESBL dapat dilakukan dengan berbagai metode diantaranya menggunakan disc approximate method (DAM), threedimensional test, Etest ESBL strips, Vitek ESBL Card, double disc, pheonix dan lain-lain. Deteksi ini memiliki sensitivitas dan spesifisitas yang berbeda. ${ }^{26}$

Peningkatan prevalensi bakteripenghasil ESBL dapat disebabkan oleh kurangnya perhatian terhadap skrining ESBL di laboratorium dari isolat klinis.Hasil penelitian yang berbeda dapat disebabkan oleh perbedaan jumlah isolat yang diteliti. Perbedaan metode yang digunakan untuk uji ESBL dan jenis sampel juga dapat memberikan hasil penelitian yang beragam.

\section{KESIMPULAN}

Karakteristik pasien yang menggunakan kateter urin berdasarkan umur terbanyak usia 4655 tahun, jenis kelamin wanita, lama pemakaian kateter selama 2-5 hari dan seluruh sampel yang mengalami pertumbuhan dengan jumlah koloni $>10^{5}$ $\mathrm{cfu} / \mathrm{mL}$. Bakteri terbanyak adalah bakteri Gram negatif berupa Escherichia coli.

Antibakteri yang memiliki sensitivitas tertinggi terhadap bakteri Gram negatif adalah chloramphenicol dan fosfomycin masing-masing $77,7 \%$, diikuti amikacin, gentamicin, tigecyclin masing-masing 66,6\%. Antibakteri yang memiliki sensitivitas tertinggi terhadap bakteri Gram positif adalah amoxicillin-clavulanat, azytromicin, cefazolin, cefepime, cefoxcitin, ceftriaxon, ciprofloxacin, chloramphenicol, linezolid, meropenem dan trimethropim-sulfamethoxazol masing-masing $100 \%$.

Pada uji skrining ESBL ditemukan Escherichia coli (40\%) dan Klebsiella sp, Acinetobacter sp dan Pseudomonas $s p$ masing-masing sebanyak (20\%). Pada uji konfirmatif tidak ditemukan bakteri batang Gram negatif penghasil ESBL. Resistensi antibiotik tidak bisa dinilai karena tidak ditemukannya bakteri Gram negatif penghasil ESBL.

\section{DAFTAR PUSTAKA}

1. Purnomo BB.. Dasar-dasar urology. Jakarta: Sagung Seto; 2000; 37-61

2. Tanagho E.A. Lange medical books. Smith's general urology, sixteenth edition. New York: 2004.

3. Bircan Z. 2002. Review article urinary tract infection and the pediatricians. Internasional Pediatrics. 17(3): 143-44.

4. Rusdidjas, Ramayati R. Infeksi saluran kemih. In: Alatas H, Tambunan T, Trihono PP, editor. Nefrologi Anak. Edisi 2. Jakarta: Balai Penerbit FKUI; 2004; 142-61.

5. Georing RV, Dockrell HM, Zuckerman M, Wakelin D, Roitt I, Mims CMedical Microbiology, $4{ }^{\text {nded. }}$ Mosby Elsevier; 2008; 255.

6. Chenowet CE,Saint S.. Infection assosiated with urinary catheters. In: Seifert H, Jansen B, Farr BM, editors. Catheter-related Infection. $2^{\text {nd }}$ ed. New York: Marcel Dekker; 2006; p.490-518.

7. Domingo KB, Mendoza MT, Torres TT. Catheter-related urinary tract infection: 
incidence, risk factor, and microbiologic profile. Phil J Microbiol Infect Dis. 28(4): 1999; 133-38

8. Forbes BA, Sahm DF, Weissfeld AS. Infections of the urinary tract. Bailey \& Scott's Diagnostic Microbiology $12^{\text {th }}$ edition. Missouri: Mosby Elsevier; 2007; 842-55

9. Sepalanita W. Pengaruh perawatan kateter urin Indwelling model American Association of Critical Care Nurses (AACN) terhadap bakteriuria di RSU Raden Mattaher Jambi. Universitas Indonesia: 2012

10.Endriani R. Identifikasi Bakteri Batang Gram Negatif Penghasil Extended Spectrum Beta Lactamase (ESBL) pada Pasien Infeksi Saluran Kemih (ISK) dengan Kateterisasi Urin di Bagian Penyakit Dalam RSUD Arifin Achmad Provinsi Riau; Fakultas Kedokteran Universitas Riau: 2011.

11. Bradford PA, Dean CR. Resistance of Gram negative bacilli to antimicrobial. In: Fong IW, Drlica K, editors. Antimicrobial resistance \& implications for the Twenty-First Century. New York: Springer Science+Bussines Media, LLC; 2008; p. 97-159.

12.Wirahjasa IGN dan Panji PAS. Pengelolaan infeksi akibat methicillin-resisten Staphylococcus aureus. Lab SMF Anestsi Fakultas Kedokteran Universitas Udayana / RSUD Sanglah: 2012; 2.[Diakses 20 april 2013]. Tersedia dalam: http://perdici.org/wp-content/ uploads/mkti/2012-02-03/mkti2012-0203$\underline{135143}$

13.Husada S, Hardjowijodo S, Kuntaman, Widodo JP, Gardjito W.. Perbandingan dan Penyebaran Escheriacia coli dan Klebsiella pneumonia penghasil extended spectrum beta lactamase pada isolat urine pasien Pria dengan kateter dan tanpa kateter. JURI. 15(1); 2008; 15-20.

14.Prajariu A, Firmanti SC, Isbandrio B. Infeksi oleh bakteri penghasil extended spectrum betaLaktamase (ESBL) di RSUP DR. Kariadi Semarang: Faktor Risiko Terkait Penggunaan Antibiotik. Semarang: Universitas Diponegoro; 2010.

15.Bhardwaj R, Pickard R, Carrick-Sen D, Brittain K. Patient' perpective on timing of urinary catheter removal after surgery [Jurnal]. British: 2012

16.Al-Hazmi, Hamdan. Role of duration of catheterization and lenght of hospital stay on The Rate of Catheter-Related Hospital-Acquired Urinary Tract Infection; 61 (7). 2015; 41-7

17. Karjono BJ, Susilaningsih N, Purnawati R. Pola kuman pada penderita infeksi saluran Kemih di RSUP Dr Kariadi Semarang; 17(2). Semarang. 2009;119-24

18.Sari EWP. Hubungan barrier nursing dan kateterisasi urine dengan kejadian nosokomial urinary tract infection pada pasien terpasang indwelling Kateter Tahun 2013-2014 (Studi di Rumah Sakit Umum Haji Surabaya). Surabaya : Universitas Airlangga

19. Mody L, Meddings J, Edson BS, Trautner BW, Stone ND. Enhancing resident safety by Preventing Healthcare-Associated Infection: A NationalInitiative to Reduce CatheterAssociatedUrinary Tract Infections in Nursing Home. Inggris : July, 2015; Tersedia dalam : http://cid.oxfordjournals.org/

20. Healtcare-associated Infections(HAIs). Catheterassociated urinary tract infections (CAUTI) Toolkit. Alanta : Centers for Disease Control and Prevention. 2015. Tersedia dalam : www.cdc.gov/HAI/pdfs/toolkits/ CAUTItoolkit 3 10.pdf

21.Samirah, Darwati, Windarwati, Hardjoeno. Pola dan sensitivitas kuman di penderita infeksi saluran kemih [Indonesian Journal of Clinical Pathology and Medical Laboratory]; 12(3). 2006; 110-13

22.Febrianto AW, Mukaddas A, Faustine I. Rasionalitas penggunaan antibiotik pada pasien infeksi saluran kemih (ISK) di Instalasi Rawat Inap RSUD Undata Palu Tahun 2012 [Online Jurnal of Natural Science];2 (3). 2013:20-9

23. Yuwono. Identifikasi gram gen SHV pada Enterobactericeae produsen extended spectrum beta lactamase (ESBL). Departemen Mikrobiologi Fakultas Kedokteran Universitas Sriwijaya. Palembang. 2012

24.Wahjono H. Pidato Pengukuhan peran Mikrobiologi klinik pada penanganan penyakit 
Rita Endriani, dkk, Bakteri dan Multiresisten Obat

Infeksi. Semarang: Universitas Diponegoro; 2007; 20-8.

25.Al-dahmoshi HM. What is the difference between ESBL, KPC, MBL and AmpC. University of Babylon: 2014
26.Wiegand I, Geiss HK, Mack D. Sturenburg E, Seifert H. Detection of extended Spectrum â Lactamase among Enterobacteriaceae by Use of Semiautomated Microbiology System and Manual Detection Procedures. J Clin Microbiol. 2007; 45(4): 1167-74 